\title{
Localization as a paradigm of urban development
}

\author{
Natalia Iudina* \\ The Moscow Institute of Architecture, Urban planning Department, 107031 Moscow, Russia
}

\begin{abstract}
Today globalisation appears to evoke a set of problems, including spatial inequality and the necessity arises to elaborate an alternative paradigm. There are already known plenty of location theories, among which industrial regions or clusters appeal to local relations rather than global economic system. Being a perspective model of urban development, it is still hardly embodied in urban planning to solve regional problems efficiently. The article intends to contribute to the theory of clusters and adapt it to socio-economic principles which identify the existence of towns. The case of small towns and settlements illustrates how local potentials can be used for sustainable urban development.
\end{abstract}

\section{Introduction}

Despite the number of strategies aiming territorial cohesion both in Russia and Europe the issue of imbalance in urban development between large cities and small settlement is still relevant. As recent articles and reports state, [1, p. 36], [2] mega-cities squeeze out resources from agglomerations bringing about suburban degradation as well as rural territories' decline. The further the more hyper-concentration and globalization are recognized as unsustainable models of urban development, and the necessity of redistribution arises [3]. In theoretical terms the issue requires the design of an alternative strategy of gaining territorial cohesion and equality That is also to accent the need for a holistic model for sustainable urban development [4, p. 125]. In practice, additional nodes of development should be pointed out to provide tangible effect of the strategy.

Despite the constant reference to positive agglomeration effects [1, pp. 1,9,25,107], the fact is that the infrastructural density characterizes predominantly small and thus compact urban formations and define their creative potential [5]. Moreover, some other works states intellectual potential [6] and networking capacity [7]. From economic point of view small local centers are to rely on SMEs, as they are capable of using the best of them. The backflash is the resulting socially coherent environment [8], [9].

The critical approach leads to a conclusion that concentration of capital threatens small systems both enterprises and urban forms. [8, p. 369], and thus, they especially require urgent measures for recovery. And the number of methods are already present to suggest an alternative way for urban development appropriate for small towns and settlements. Locally

\footnotetext{
*Corresponding author: yudina.natalia@marhi.ru
} 
oriented they are based on the advantages of urban formations, considered as autonomous structures. Cluster is such model and the tool for enhancement of small towns economics. In the light of the above discussion the article intends to contribute to the field regional urban planning in the aspect of equitable redistribution of sources. The goal of this paper is to define local development as a new way of urban development concentrated on alternative, small urban nodes. The objectives of the research are to:

- Reveal locally-oriented approaches within the models of regional development

- Trace linkages between economic and urban clusters

- Adapt features of social justice to urban cluster

\section{Methods. Local models of regional development}

\subsection{Retrospective of location theories}

In order to determine an appropriate local approach for regional development a comparative analysis is conducted. The existing regional development models are juxtaposed.

The key aspect of comparison is the type of theory or model. While D. Ricardo, A. Smit, B. Ohlin, V. Leontiev place a particular importance on absolute and comparative regional advantages to define their specialization and, consequently, make location decisions, the evolution of theories predominantly followed the branch of locational approach.

Theories of I. Tünen, W. Laundhardt. A. Weber, V. Christaller, A. Lösch are searching for the principles of agricultural, industrial, urban location and thus are closely connected to issues of spatial development. A. Lösch was the first to combine all the theories into a coherent study. This theory of location goes in details of the spatial organization of economics and shift the field of research to economic regions - local spatial structures. Following the model of Christaller, Lösch divide all the territories into compact segments and deduce a set of regularities Some of the fundamental principles are:

- Location provides maximal advantages for consumers and producers;

- Location occupies the territory completely;

- All market (selling) areals have least possible (compact) form.

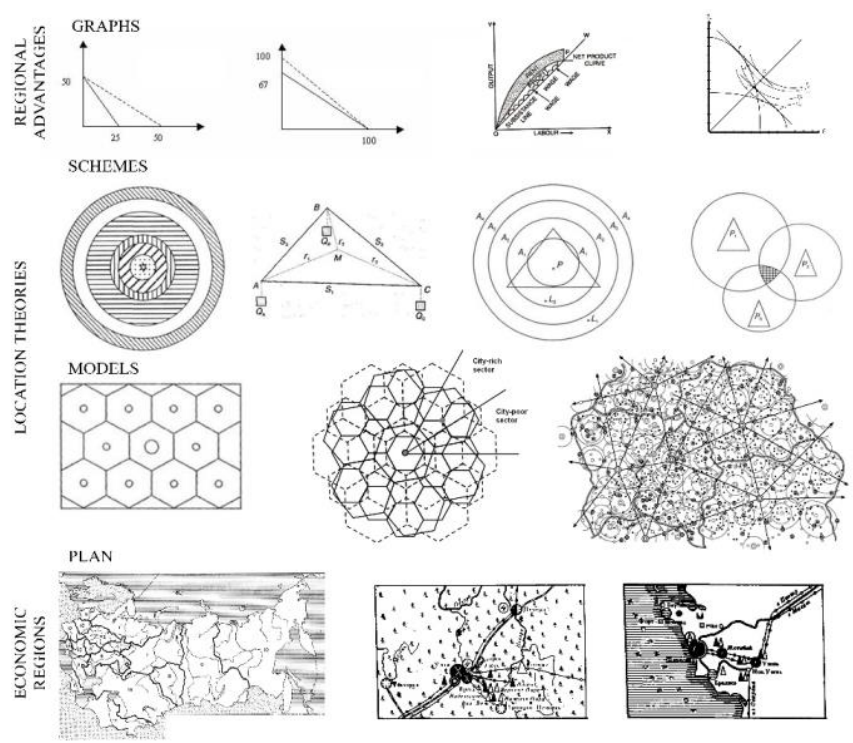

Fig. 1. Retrospective of regional theories. Visualisation 
Though A. Lösch operated in scale of economic regions, in his opinion all of them were included in the global system of labour division. The next logical step - to consider economic regions as self-contained economic structures - was made by soviet scientists economic geographers V. Vernadskiy, N. Baranskiy, N. Kolosovskiy, A. Granberg. The theory of economic zoning is coauthored by N. Baranskiy, N. Kolosovskiy and suggests the association of industries within geographically approachable area. The economic basis for such an association is the combination of technological processes, establishment of an enclosed energetic and productive cycle. The resulting general units were called industrial regions, or, not commonly used then, clusters, and indeed formed the system of resources and goods redistribution on a local level. Basing on principles of equity rather than liberty the model confirmed effectiveness, but was abandoned after the ruin of the Soviet Union.

\subsection{From economic regions to clusters}

Global spatial concentration makes the issue of local redistribution arise again. Clusters as economic forms were discovered some time after the abovementioned researchers by $\mathrm{M}$. Enright, W. Aisard and M. Porter. Their theory of clusters was far more limited, however it accented some basic features of clusters:

- common capital resources and conditions of production;

- conditions of internal demand;

- diversity of functions;

- inner competitiveness and structuralization;

- dependence on externalities and networking potential;

- $\quad$ spatial flexibility, scalability.

Since the theory spread and was commonly approved, the cluster have been used in narrow sense, as a group of enterprises within the definite geographical area. [10, p. 130] The contemporary evolutionary path of location theories makes cluster only a regional, i.e. territorially defined, enterprise, and hardly an instrument of positive transformations. The unprecedented popularity of cluster strategies in regional economic development was caused by the dramatic shift in economic paradigm in the direction of information technologies. Cluster appeared to be quite efficient for the process of knowledge-based production.

Innovative process depends strongly on close interrelations of research and industry. It works on the basis of so called social capital, and so cluster strategies reoriented to develop social aspect. The more the further cluster can't be considered solely as an economic tool. In this article cluster is considered in a broader sense as a set of social, cultural, economic and spatial principles for the development of an urbanized territory.

To summarize, cluster is seen deeply founded in previous theoretical research method of local development. Its potential is not fully revealed and exploited today, which shows the necessity of its specific connection to spatial structures.

\section{Results. From cluster to urban cluster}

If one tries to adapt economic essence of cluster to tangible, physical features of territory, a number of constraints appear.

As an economic system cluster demands the features to bring externalities about: an appropriate number of participants, their common interests, the need for services and resources with the simultaneous cost reduction. Cluster evolves dynamically in the direction of increasing value and knowledge, linking its members. 
Spatial features of cluster, its geography is defined by the capability of knowledge transfer, closely connected with mobility and transport. But it's impossible to ignore the major influence of cultural linkages, personal preferences, and social hierarchy. In urban clusters these features may be considered even more influential, as a town penetrated by the network of human relations and areals of communal interests. Social boundaries, as well as economic, play an important role in systematic relations and its spatial expression.

Table 1. Comparison of economic and urban clusters.

POINT OF ECONOMIC CLUSTERS URBAN/REGIONAL

COMPARISON

CLUSTERS

\begin{tabular}{|c|c|c|}
\hline $\begin{array}{l}\text { ECONOMIC } \\
\text { INCENTIVE }\end{array}$ & $\begin{array}{l}\text { Capital resources and } \\
\text { conditions of production }\end{array}$ & $\begin{array}{c}\text { Social-commercial- } \\
\text { administrative cooperation, } \\
\text { cohesion }\end{array}$ \\
\hline INNOVATIVE BASIS & Global demand, niche & Local potential \\
\hline $\begin{array}{l}\text { DIRECTION OF } \\
\text { DEVELOPMENT }\end{array}$ & External & Internal \\
\hline $\begin{array}{c}\text { TYPE OF } \\
\text { DISTRIBUTION }\end{array}$ & $\begin{array}{c}\text { Internal demand, external } \\
\text { market }\end{array}$ & $\begin{array}{l}\text { Local orientation and } \\
\text { redistribution }\end{array}$ \\
\hline STRUCTURE & Temporal cooperation & Territorial fixity \\
\hline CONNECTIONS & Economic, partner & Territorial and social \\
\hline STAKEHOLDERS & Firm/land owners & Citizens and administration \\
\hline DIVERSITY & $\begin{array}{c}\text { Collection of industries of same } \\
\text { or adjacent branches }\end{array}$ & $\begin{array}{l}\text { Historical and cultural } \\
\text { functional diversity }\end{array}$ \\
\hline $\begin{array}{c}\text { SELF- } \\
\text { STRUCTURALIZATION }\end{array}$ & $\begin{array}{c}\text { Inner competitiveness and } \\
\text { structuralization }\end{array}$ & $\begin{array}{c}\text { Integration into urban and rural } \\
\text { environment }\end{array}$ \\
\hline EXTERNALITIES & $\begin{array}{l}\text { Global effects and inner } \\
\text { economic alliances }\end{array}$ & Social and cultural network \\
\hline TRANSFORMABILITY & Spatial flexibility, scalability & Connections' flexibility \\
\hline LIMITATIONS & Industry branches & $\begin{array}{c}\text { Communal interests } \\
\text { Infrastructural boundaries }\end{array}$ \\
\hline
\end{tabular}

The table shows that in urban cluster every aspect of a traditional cluster system is adapted to local specificity and identity. Structural aspects and innovative basis are transformed to the opposite - from mobility to fixity as cluster gets rooted in an area. By the way of contrast, some tangible matters of cluster as economic base, connections and externalities shift to socio-cultural field. That confirms that the essence of cluster stays intact. One of the principle limitations of urban cluster which impedes its scaling is physical capability of infrastructure, i.e. space and time to overcome for effective management and control. This obstacle can be compensated by digital coordination system independent of the problem of remoteness.

In the end, let us generalize and list the main features of an urban cluster:

- local orientation, territorial fixity;

- integration into urban and rural environment; 
- $\quad$ historically determined diversity of functions;

- $\quad$ social externalities and networking potential;

- limited scalability (compensated by digital technologies).

Hence, urban cluster is defined by the author as cross-disciplinary approach to the production of self-sufficient urban structure, in which cohesion is provided by the network of infrastructural connections between economic subjects, aiming at the realization of local potential and supporting of urban sustainability.

\section{Discussion. Social issues of cluster}

\subsection{On the way to social justice}

Till now clusters have always been formed by an initiative of large commercials, aiming at maximizing profits and exploiting urban territory and citizens. Meanwhile the main stakeholders of clusters are local people, which form the major part of working force, which are concerned of growth of employment and enhancement of working conditions these of are especially significant for economically backward regions and urban formations. [8, p. 365] Clusters must consider local needs, [11, p 102] as their framework consists of social relations, depends on their solidity and is supported by the resource of 'culture gene' of a town. [8, p. 369]

Clusters are mainly demand-based, that's why commercials act in their own interest. That defines the depleted state of rural and small urban settlements, which are distinguished by relatively low budgets. This results in physical degradation which in turn evokes socioeconomic pressure within an urban area. [12, p. 329]

Communal interests during the process of cluster development can be provided by different methods, among which clusters associations are much more effective for achieving social goals. The social strategy of cluster's evolution commences when the cluster council. The most of growing clusters are primarily based on mid-skilled labour. Often these are local people with a low level of education and limited mobility, which have nothing to do with the existing working conditions. [12]

The scale of business must be changed to the organizational control and linkages. Nonexclusive economics which are oriented to citizens - members of local association. Given the social participation in management of cluster the productive model will undoubtedly work in the interests of town dwellers and cluster workers. [8, p. 374]

\subsection{Small towns potential}

The discussion puts forward the question whether urbanized areas of any scale and type is capable of forming a cluster. Returning to small towns and settlements, their vulnerability was already mentioned, as well as a potential of an alternative pole of growth. The fact is urban cluster aims at local area and acts in order to structure economic and spatial interrelations. Small, compact settlements, as recent researches state, demonstrate a tendency for networking, [7] which is a key feature of cluster model. Cultural identity which predominantly form the functional foundation of small towns allows them to produce unique goods and services. Given this identity, small towns can be seen as self-sufficient clusters.

For instance, basing on the unique production (handicrafts, identity, local services, recreation zones), a small town can form initial network connections. [7, p. 166] There are some examples to approve the small towns innovative, cluster-forming capacity, such as Italian project Cultural Districts, accenting historical potentials of regions: musical 
instruments of Cremona, an original food production of Emilia-Romagna, etc., or American and European initiatives such as: MT Airy cluster in North Carolina, which evolved on the advantage of Hickory transport node proximity, Hay-in-the-Wye in Wales and Redu in Belgium with their transferable practice of vintage books sales. [8, p. 375]]

Thus, the conducted research enriches the field of location theories and cluster theory. Cluster is considered as a tool for urban development of small towns and cities for the first time. Though social aspects of cluster were already considered by some researches, here they are specifically applied to vulnerable urban formations. To put it another way, urban clusters can be used as an effective tool for local development, especially for those urban areas, which are devoid of alternative paths.

\section{Conclusions}

To sum it up, global economic systems make small urban and rural formations stagnate and degrade, which leads to inequalities. Nevertheless, there is a growing interest in local models of urban development. The article reveals the most locally oriented approaches among theories of regional location and makes a contribution to theory of clusters. Urban clusters, characterized by the author present tangible model for sustainable urban development. Though the discussion is present, whether social matters are sufficiently expressed in cluster approach, there are elaborated a number of principles to provide social control and coordination. Having much in common with clusters, small towns and settlements are seen to be perspective nodes for urban development on the innovative basis and through the potential of networking.

\section{References}

1. "Seventh Report on Economic, Social and Territorial Cohesion," 2017. Available at https://ec.europa.eu/regional_policy/sources/docoffic/official/reports/cohesion7/7cr.pdf[ Accessed 20 January 2021]

2. J. Utt, W. Cox, The costs of sprawl reconsidered: What the data really show, (Washington, DC: National Academy Press, 2004)

3. D. Harvey, Social Justice and The City (Athens, DG: the University of Georgia Press, 2008)

4. D. Throsby, Economics of culture (Cambridge: Cambridge University Press, 2001)

5. E. Resseger, M. Glaeser, The complementarity between cities and skills, in Journal of Regional Science, 50(1) (2020) p. 221-244 Available at SSRN: https://ssrn.com/abstract $=1426454$

6. Y. Uskova, V. Lyubovnyi, Intellectual potential of Russian cities as a factor of economy transition to innovative development, in Vestnik Moskovskogo universiteta, 2 (2009) p. 51-57 Available at https://elibrary.ru/download/elibrary_12965959_91389138.pdf

7. M. Sheresheva, M. Oborin and A. Kostanyan, Assessment of the development potential of small towns and directions of its effective use, E-Journal public administration, $\mathbf{6 5}$ (2017). p. 162-175 Available at http:/ejournal.spa.msu.ru/uploads/vestnik/2017/vipusk_65._dekabr_2017_g./regionalnaja_ek onomika/sheresheva_oborin_kostanyan.pdf

8. S. Rosenfeld, Expanding opportunities: Cluster Strategies That Reach More People and More Places, European Planning Studies, 4 (2003) pp. 359-377 Available at https://doi.org/10.1080/09654310303643 
9. P. T. Roundy, "Small town" entrepreneurial ecosystems: Implications for developed and emerging economies, Journal of Entrepreneurship in Emerging Economies, 9(3) (2017) pp. 238-262, Available at SSRN: https://ssrn.com/abstract=3011408

10. V. Grishin and G. Gagarina, Regional economics : student book (Moscow: KNORUS, 2020)

11. M. Murray, Urbanism of Exception: The dynamics of Global City Building in the Twenty-First Century (Cambridge: Cambridge University Press, 2017)

12. D. Harvey, Spaces of capital : towards a critical georgraphy (New York: Routledge, 2001) 